\title{
Effect of Sn Addition in Gas Phase Hydrogenation of Acetic Acid on Alumina Supported PtSn Catalysts
}

\author{
Ke Zhang $\cdot$ Haitao Zhang $\cdot$ Hongfang Ma $\cdot$ \\ Weiyong Ying $\cdot$ Dingye Fang
}

Received: 2 September 2013/Accepted: 5 February 2014/Published online: 20 February 2014

(C) The Author(s) 2014. This article is published with open access at Springerlink.com

\begin{abstract}
Alumina supported Pt, Sn and PtSn catalysts were prepared by impregnation and tested in the gas phase hydrogenation of acetic acid, and characterized by $\mathrm{N}_{2^{-}}$ physisorption, XRD, $\mathrm{H}_{2}$-TPR, $\mathrm{H}_{2}$-pulse chemisorption, $\mathrm{H}_{2}$ TPD, DRIFTS (diffuse reflectance infrared Fourier transform spectroscopy), XPS, electron microscopy techniques (TEM, HRTEM and EDX). Results show that Sn addition to $\mathrm{Pt} / \mathrm{Al}_{2} \mathrm{O}_{3}$ catalyst can improve the conversion of acetic acid and suppress the production of by-products, as well as enhance the selectivity towards ethanol. The optimization of activity and selectivity can be achieved by changing reaction temperature and pressure. Characterizations indicated that the better performance of $\mathrm{PtSn} / \mathrm{Al}_{2} \mathrm{O}_{3}$ catalyst is due to the formation of PtSn alloy and $\mathrm{Pt}_{-} \mathrm{SnO}_{\mathrm{x}}$ species.
\end{abstract}

Keywords PtSn catalyst - Hydrogenation - Acetic acid . Ethanol

\section{Introduction}

As one of the most important oxygen-containing organic materials, ethanol has a variety of applications, such as pharmaceutical and perfume preparation, as solvent and antiseptic, and as additives to fuel motor vehicles. Most ethanol in the world is produced through fermentation of agricultural products, such as corn and sugar cane, and only a small fraction is made synthetically. The chemosynthesised

\footnotetext{
K. Zhang $\cdot$ H. Zhang $\cdot$ H. Ma $\cdot$ W. Ying $(\bowtie) \cdot D$. Fang Engineering Research Center of Large Scale Reactor Engineering and Technology of the Ministry of Education, State Key Laboratory of Chemical Engineering, East China University of Science and Technology, Shanghai 200237, China e-mail: wying@ecust.edu.cn
}

ethanol is mainly manufactured from ethylene hydration [1]. This process is conducted by reacting ethylene with steam at $573 \mathrm{~K}, 6.0-7.0 \mathrm{MPa}$ and only $5 \%$ of the ethylene is converted into ethanol at each pass. However, the food crisis and the oil depletion make the aforementioned routes unattractive for the large scale production of ethanol. More recently, much attention has been paid to the study of conversion of coal-based starting materials such as methanol or synthesis gas to ethanol. They include homologation and carbonylation processes and the direct conversion of synthesis gas to ethanol [2,3]. Unfortunately, all the synthetic methods are not so satisfactory till now.

From the point of industrial view, a desirable synthesis method should be direct and robust and applicable on a large scale, and catalytic hydrogenation of acetic acid would meet these demands if suitable catalyst is available. On one hand, acetic acid is currently manufactured by three alternative processes: acetaldehyde oxidation, $n$-butane oxidation and methanol carbonylation, and the homogeneous methanol carbonylation technology developed by Monsanto exhibits high selectivity (based on methanol $99 \%$ and carbon monoxide $85 \%$ ) and can be operated under mild conditions (453-493 K, 3.0-4.0 MPa) [4]. On the other hand, theoretically, acetic acid can be reduced to ethanol according to the following stoichiometry,

$\mathrm{CH}_{3} \mathrm{COOH}+2 \mathrm{H}_{2} \leftarrow \mathrm{C}_{2} \mathrm{H}_{5} \mathrm{OH}+\mathrm{H}_{2} \mathrm{O}$

without the hazards of pollutants.

Furthermore, the study of acetic acid hydrogenation has attracted much attention during the past decades. Pestman et al. [5-7] have accomplished a series of experiments to explore the reactions of carboxylic acids on oxides and the products they obtained from acetic acid are acetone and aldehyde. Studies conducted by Rachmady and Vannice indicated that $\mathrm{Pt}$ supported on oxides is a promising 
catalyst for acetic acid hydrogenation and a product distribution of $50 \%$ ethanol, $30 \%$ ethyl acetate and $20 \%$ ethane can be acquired on $\mathrm{TiO}_{2}$ supported Pt catalyst $[8,9]$.

The addition of a second metal to noble metal catalysts can modify their catalytic behavior, such as in the case of bimetallic PtSn catalysts. Sn added to platinum-based catalysts has proven to be beneficial to the activity maintenance and/or can modify the selectivity of catalysts in many processes, such as selective oxidation of CO [10], soot oxidation [11], catalytic reduction of NO [12], paraffins dehydrogenation [13-17], and hydrogenation of $\alpha, \beta-$ unsaturated aldehydes [18, 19]. The research of Coloma et al. $[20,21]$ revealed that the presence of Sn can greatly enhance the catalytic activity and improve the selectivity towards $\mathrm{C}=\mathrm{O}$ bond hydrogenation in the gas phase hydrogenation of crotonaldehyde, and the reports of Miguel et al. [18] and Serrano-Ruiz et al. [19] had drew similar conclusions.

To our knowledge, the effect of Sn addition in aluminasupported PtSn catalyst on acetic acid hydrogenation has not been investigated yet. In this study, alumina-supported bimetallic PtSn catalysts and monometallic Pt, Sn catalysts were prepared, characterized and tested in the gas phase hydrogenation of acetic acid.

\section{Experimental}

\subsection{Catalyst Preparation}

Three bimetallic $\mathrm{PtSn} / \mathrm{Al}_{2} \mathrm{O}_{3}$ catalysts with different $\mathrm{Pt} / \mathrm{Sn}$ ratio (1/3, 2/2 and 3/1) and constant total loading (2.0 wt $\%)$ were prepared by co-impregnation. After being ground and sieved to desired size $(0.3-0.45 \mathrm{~mm})$, the $\mathrm{Al}_{2} \mathrm{O}_{3}$ support was calcined at $823 \mathrm{~K}$ for $12 \mathrm{~h}$ to remove organic impurities before impregnated with a aqueous solution of tin salt $\left(\mathrm{SnCl}_{2} \cdot 4 \mathrm{H}_{2} \mathrm{O}\right)$ and platinum salt $\left(\mathrm{H}_{2} \mathrm{PtCl}_{6} \cdot 6 \mathrm{H}_{2} \mathrm{O}\right)$. After aged for $12 \mathrm{~h}$ at room temperature, the catalysts were dried at $293 \mathrm{~K}$ over night and then calcined in air at $823 \mathrm{~K}$ for $12 \mathrm{~h}$. For the purpose of comparison, two monometallic catalysts with a nominal loading of $1.0 \mathrm{wt} \%$ were also prepared. They were subjected to the same procedure other than that the impregnation solution only contains $\mathrm{SnCl}_{2}$ $4 \mathrm{H}_{2} \mathrm{O}$ or $\mathrm{H}_{2} \mathrm{PtCl}_{6} \cdot 6 \mathrm{H}_{2} \mathrm{O}$. The catalysts were denoted as $\mathrm{aPtbSn} / \mathrm{A}$, where $\mathrm{b}$ and a represent ten times the nominal weight percentage of $\mathrm{Sn}$ and $\mathrm{Pt}$, respectively, and A represents alumina. For instance, $\mathrm{PtSn} / \mathrm{Al}_{2} \mathrm{O}_{3}$ catalyst with a $\mathrm{Pt} / \mathrm{Sn}$ ratio of $1 / 3$ was labeled as $5 \mathrm{Pt} 15 \mathrm{Sn} / \mathrm{A}$.

\subsection{Catalyst Characterization}

The BET (Brunauer Emmett Teller) surface area, average pore diameter, and pore size distribution of the catalysts and the support were determined by means of nitrogen physisorption using a Micromeritics ASAP 2020M automated system. All samples were degassed at $500 \mathrm{~K}, 1.3 \mathrm{~Pa}$ for $6 \mathrm{~h}$ before $\mathrm{N}_{2}$ adsorption.

$\mathrm{X}$-ray diffraction (XRD) powder patterns of the catalysts were recorded with a Rigaku D/max 2550 diffractometer using nickel filtered $\mathrm{Cu} \mathrm{K} \alpha$ radiation $(\lambda=1.54056 \AA)$ at room temperature. The X-ray tube was operated at $40 \mathrm{kV}$, $100 \mathrm{~mA}$ and scanned from $10^{\circ}$ to $80^{\circ}$.

The morphology and particle size of the catalysts were observed using a JEOL-JEM 2100 transmission electron microscope operated at $100 \mathrm{kV}$. High resolution TEM combined with energy-dispersive X-ray microanalysis (EDX) was performed on a Tecnai G2 F30 S-TWIN electron microscope operating at $300 \mathrm{kV}$. The catalysts were ground to 300 mesh and dispersed in absolute ethanol by ultrasonic for $30 \mathrm{~min}$, then a drop of the prepared solution was added to a carbon-coated copper grid. The catalysts were exposed to an infrared red lamp for $30 \mathrm{~min}$ to remove the ethanol before scanning.

Hydrogen temperature-programmed reduction $\left(\mathrm{H}_{2}-\mathrm{TPR}\right)$ was performed on Micromeritics AutoChem II 2920. Generally, $0.20 \mathrm{~g}$ sample was placed in a quartz U-tube reactor and calcined in situ at $773 \mathrm{~K}$ for 60 min under $\mathrm{Ar}$ (99.99\%) atmosphere and then cooled down to room temperature. The reductive mixture $\left(10 \% \mathrm{H}_{2}\right.$ in $\left.\mathrm{Ar}\right)$ was fed to the reactor at a flow rate of $50 \mathrm{~mL} \mathrm{~min}{ }^{-1}$. The TPR experiments were carried out from room temperature to $1,073 \mathrm{~K}$ with a ramp of $10 \mathrm{~K} \mathrm{~min}^{-1}$ and the hydrogen consumption was monitored by a thermal conductivity detector (TCD) after the base line was stable.

$\mathrm{H}_{2}$-pulse chemisorption experiments were performed to analyze the Pt dispersion of the catalysts in the same system as adopted in TPR. The samples were reduced under $\mathrm{H}_{2}\left(99.99 \%, 30 \mathrm{ml} \mathrm{min}{ }^{-1}\right)$ at $623 \mathrm{~K}$ for $2 \mathrm{~h}$, then

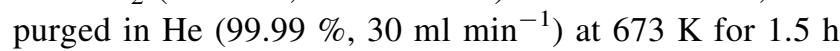
and cooled down to $303 \mathrm{~K}$ in flowing $\mathrm{He}\left(30 \mathrm{ml} \mathrm{min}^{-1}\right)$. Calibrated pulses of $\mathrm{H}_{2}$ were injected into the system repeatedly until no further $\mathrm{H}_{2}$ consumption was noted, and the time between pulses was 4 min. $\mathrm{H}_{2}$-TPD experiments were performed after $\mathrm{H}_{2}$ pulse chemisorption in the same system and the spectra was recorded from 303 to $1073 \mathrm{~K}$.

DRIFTS (diffuse reflectance infrared Fourier transform spectroscopy) of acetic acid were carried out to determine the nature of the adsorbed species on the catalysts in a spectrometer (Nicolet 6700, Thermo, USA) which had been modified to allow in situ catalyst pretreatment. The infrared cell was equipped with temperature controlled parts and $\mathrm{ZnSe}$ window. The catalysts were reduced in situ for $2 \mathrm{~h}$ under atmospheric pressure by hydrogen at $623 \mathrm{~K}$ (30 $\mathrm{ml} \mathrm{min}^{-1}, 5 \mathrm{~K} \mathrm{~min}^{-1}$ ) and purged with pure nitrogen $(99.99 \%)$ for $1 \mathrm{~h}$ at $623 \mathrm{~K}$. Acetic acid was introduced 
into the system by passing a $\mathrm{N}_{2}$ flow through a glass vessel containing liquid acetic acid $(99.95 \%)$ at room temperature under a pressure of $0.1 \mathrm{MPa}$. After the catalyst was saturated with acetic acid, the system was flushed with $\mathrm{N}_{2}$ for $1 \mathrm{~h}$. Infrared spectra of adsorbed species were collected at atmospheric pressure and room temperature at a resolution of $4 \mathrm{~cm}^{-1}$. Each spectrum after adsorption was referenced to that of the freshly pretreated sample just prior to introduction of the adsorbate.

Photoelectron spectra were recorded over calcined and reduced samples using an ESCALAB 250Xi (Thermo Fisher, America) photoelectron spectrometer coupled with a $\mathrm{Al} \mathrm{K} \alpha \mathrm{X}$-ray operated at $10 \mathrm{~mA}$ and $12 \mathrm{kV}$. The energy regions of the photoelectrons of interest were repeatedly scanned to get good signal-to-noise ratios. The intensity of the peaks were quantified by determining the integral of each peak after subtracting an S-shaped background and fitting the experimental peaks to Lorentzian/Gaussian lines (80\% L/20\% G). The C1 s line was taken as an internal standard at $285.0 \mathrm{eV}$.

\subsection{Catalyst Evaluation}

The activity and product selectivity of the catalysts were tested for the gas phase hydrogenation of acetic acid in a fixed bed reactor $(\Phi 14 \times 2 \times 650 \mathrm{~mm})$ under different conditions. Catalysts $(2.5 \mathrm{~g}$, about $4 \mathrm{ml})$ were reduced in situ in flowing hydrogen (0.1 MPa, $\left.100 \mathrm{ml} \mathrm{min}^{-1}\right)$ according to the following procedure: $2 \mathrm{~K} \mathrm{~min}^{-1}$ from ambient to $533 \mathrm{~K}$ and kept at this temperature for $1.5 \mathrm{~h}$ then $1 \mathrm{~K} \mathrm{~min}^{-1}$ to $623 \mathrm{~K}$ and held at $623 \mathrm{~K}$ for $2 \mathrm{~h}$. The pressure of the system was controlled by regulating the reducing valve and the back-pressure valve after the catalyst bed was cooled down to the selected reaction temperature under $\mathrm{H}_{2}$ flow. Acetic acid was pumped and transported by $\mathrm{H}_{2}$ into the system and preheated to maintain gas phase before entering the reactor. The effluent was monitored every $12 \mathrm{~h}$ so as to get a steady-state performance after passing through the condenser and the liquidvapor separator. Components of the tail gas were determined on-line and the products in the liquid phase were detected off-line by GC Agilent 7890A. In one sampling loop, $\mathrm{CH}_{4}, \mathrm{C}_{2} \mathrm{H}_{6}, \mathrm{H}_{2}$ and $\mathrm{H}_{2} \mathrm{O}$ were analyzed with a thermal conductivity detector (TCD) furnished with a molecular sieve $5 \mathrm{~A}$ packed column $(6 \mathrm{FT} \times 1 / 8 \mathrm{IN} \times 2.1 \mathrm{~mm})$ and a Hayesep Q packed column $(8 \mathrm{FT} \times 1 / 8 \mathrm{IN})$. In the other loop, C1-C6 oxy-compounds were analyzed with a flame ionization detector (FID) coupled with an HP-PLOT/ $\mathrm{Q}$ capillary column $(30 \mathrm{~m} \times 0.53 \mathrm{~mm} \times 40 \mu \mathrm{m})$ and an HP-INNOWAX $(30 \mathrm{~m} \times 0.53 \mathrm{~mm} \times 1 \mu \mathrm{m}) \quad$ capillary column. Particularly, the acetic acid left in the liquid was determined by titration.

\section{Results and Discussion}

\section{$3.1 \mathrm{~N}_{2}$-Physisorption}

The BET surface area $\left(\mathrm{S}_{\mathrm{BET}}\right)$, pore volume $\left(\mathrm{V}_{\mathrm{p}}\right)$, and average pore diameter $\left(D_{p}\right)$ of the catalysts and $\mathrm{Al}_{2} \mathrm{O}_{3}$ support are listed in Table 1. For $\mathrm{Al}_{2} \mathrm{O}_{3}$ support, the surface area is mainly formed by the micro/meso-pores. The introduction of metals could result in blockage of part of the small pores, which can be ascribed to the loss of surface areas and pore volumes, as well as the increase of average pore diameters. However, the differences among the catalysts are slight because of a low metal loading, which is similar with the report of Ayastuy et al. [10]. The $\mathrm{N}_{2}$ adsorption-desorption isotherms (Fig. 1) reveal that the catalysts and support all show the properties of type $\mathrm{H} 4$ hysteresis loop, which means that the pores are narrow slit shaped and the pore structure of the support has been changed little by metal loading [22].

Table $1 \mathrm{~N}_{2}$ physisorption results of the fresh catalysts and the support

\begin{tabular}{llll}
\hline Catalysts & $\begin{array}{l}\text { Surface area } \\
\left(\mathrm{m}^{2} \mathrm{~g}^{-1}\right)\end{array}$ & $\begin{array}{l}\text { Pore volume } \\
\left(\mathrm{cm}^{3} \mathrm{~g}^{-1}\right)\end{array}$ & $\begin{array}{l}\text { Average pore } \\
\text { diameter }(\mathrm{nm})\end{array}$ \\
\hline 10Pt/A & 167 & 0.45 & 11 \\
10Pt10Sn/A & 163 & 0.45 & 11 \\
$5 \mathrm{Pt} 15 \mathrm{Sn} / \mathrm{A}$ & 183 & 0.45 & 10 \\
15Pt5Sn/A & 175 & 0.44 & 10 \\
10Sn/A & 157 & 0.43 & 11 \\
$\mathrm{Al}_{2} \mathrm{O}_{3}$ & 222 & 0.46 & 8 \\
\hline
\end{tabular}

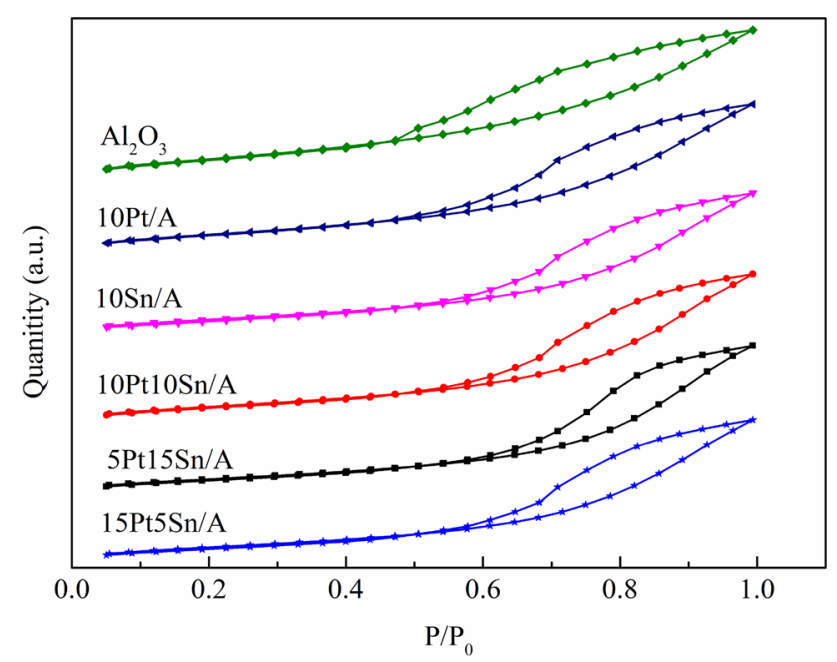

Fig. $1 \mathrm{~N}_{2}$ adsorption-desorption isotherms of the catalysts and the support 


\section{$3.2 \mathrm{XRD}$}

Figure 2 shows the XRD patterns of the catalysts and the support. The characteristic peaks of alumina located at $2 \theta=38,46$ and $67^{\circ}$ are very distinct and no other peak is detectable [23]. The absence of Pt, Sn and Pt-Sn alloy phases in our samples may be ascribed to the fact that the $\mathrm{Pt}$ and Sn are highly dispersed on the alumina support and/ or that the size of the crystallite is too small (as revealed by TEM and $\mathrm{H}_{2}$-pulse chemisorption) to be detected by XRD characterization.

\section{$3.3 \mathrm{H}_{2}$-TPR}

$\mathrm{H}_{2}$-TPR profiles of the monometallic catalysts $(10 \mathrm{Sn} / \mathrm{A}$, 10Pt/A) and the bimetallic catalysts (5Pt15Sn/A, 10Pt10Sn/ $\mathrm{A}$ and $15 \mathrm{Pt} 5 \mathrm{Sn} / \mathrm{A}$ ) are shown in Fig. 3. The reduction peak of $10 \mathrm{Sn} / \mathrm{A}$ is broad and $\mathrm{H}_{2}$ consumption is observed over a large temperature range with a maximum at about $750 \mathrm{~K}$, while monometallic 10Pt/A catalyst shows a reduction peak at about $510 \mathrm{~K}$. Bimetallic catalysts present similar reduction behavior with 10Pt/A. A broadening of reduction peaks and a shift of peak temperature towards higher zones is also observed along with the increase of $\mathrm{Sn} / \mathrm{Pt}$ ratio. These findings are similar to the reports of Hoang et al. [24]. A plausible explanation is that $\mathrm{Sn}$ species are in the vicinity of $\mathrm{Pt}$ and the coreduction of $\mathrm{Pt}$ and $\mathrm{Sn}$ occurred in bimetallic PtSn catalysts, which probably lead to the formation of $\mathrm{Pt}-\mathrm{SnO}_{\mathrm{x}}$ species or PtSn alloy [31].

\section{4 $\mathrm{H}_{2}$-Pulse Chemisorption and $\mathrm{H}_{2}$-TPD}

The Pt dispersion of the catalysts was calculated from $\mathrm{H}_{2}-$ pulse chemisorption experiments at room temperature and

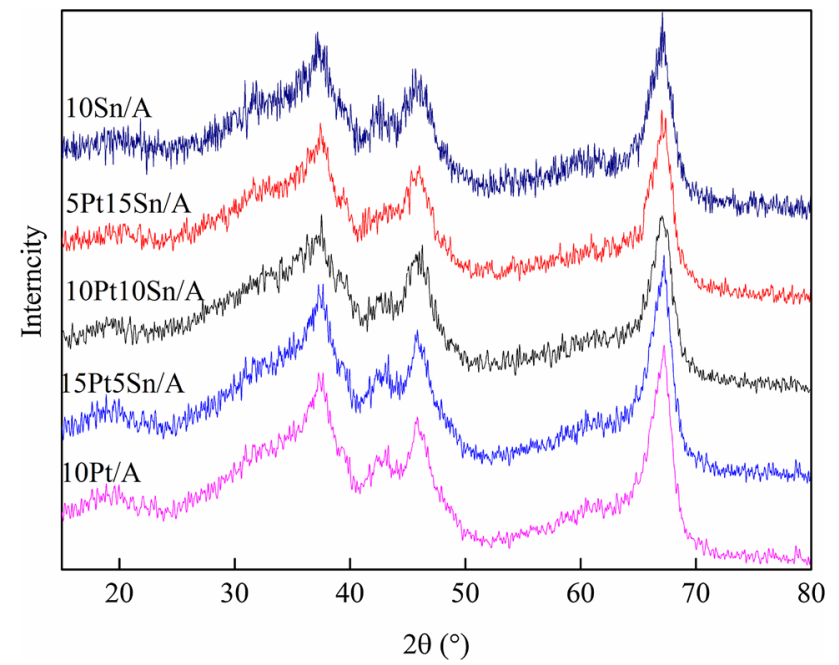

Fig. 2 XRD patterns of the catalysts displayed in Table 2, based on the assumption that $\mathrm{H} / \mathrm{Pt}=1$. Our preliminary tests of $\mathrm{H}_{2}$-pulse chemisorption indicated that $10 \mathrm{Sn} / \mathrm{A}$ and the $\mathrm{Al}_{2} \mathrm{O}_{3}$ support do not chemisorb $\mathrm{H}_{2}$. It is obviously that the introduction of $\mathrm{Sn}$ to monometallic Pt catalyst can lead to a decreased Pt dispersion, and the higher is the $\mathrm{Sn} / \mathrm{Pt}$ ratio, the smaller is the Pt dispersion. This phenomenon is also suggested by others $[21,25]$ and can be attributed to the formation of $\mathrm{Pt}-\mathrm{SnO}_{\mathrm{x}}$ species or PtSn alloy.

The characteristics of chemisorbed hydrogen on the catalysts were studied by $\mathrm{H}_{2}$-TPD. The $\mathrm{H}_{2}$-TPD profiles obtained after $\mathrm{H}_{2}$-pulse chemisorption at room temperature of the monometallic Pt and bimetallic PtSn catalysts are shown in Fig. 4. All the catalysts show two desorption peaks. The desorption peaks at low temperature region (about $380 \mathrm{~K}$ ) are prominent while the peaks at high temperature zone (near $800 \mathrm{~K}$ ) are so weak that they almost cannot be observed. Generally, low temperature desorption peaks are assigned to hydrogen desorbed from metallic Pt [26, 27], while high temperature desorption peaks are assigned to spillover hydrogen, strong

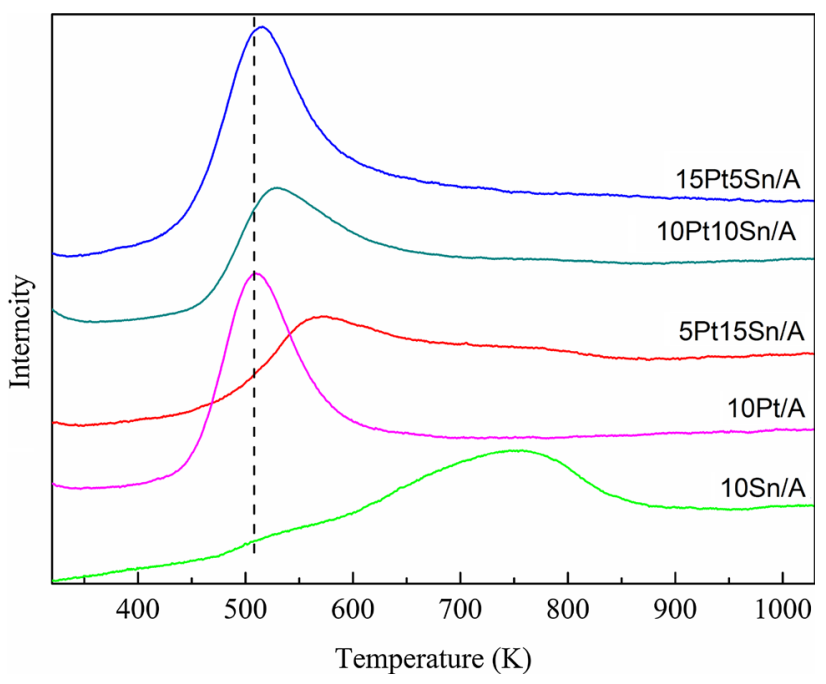

Fig. $3 \mathrm{H}_{2}$-TPR profiles of the catalysts

Table $2 \mathrm{H}_{2}$-pulse chemisorption and $\mathrm{H}_{2}$-TPD results of the catalysts

\begin{tabular}{llllll}
\hline Catalysts & $\begin{array}{l}\mathrm{H}_{2} \text {-TPD } \\
\text { peak } \\
\text { temperature } \\
(\mathrm{K})\end{array}$ & $\begin{array}{l}\text { Adsorption } \\
\text { quantity of } \mathrm{H}_{2} \\
\left(\mu \mathrm{mol} \mathrm{g} \mathrm{g}^{-1}\right)\end{array}$ & $\begin{array}{l}\text { Pt } \\
\text { dispersion }\end{array}$ & $\begin{array}{l}\text { Particle } \\
\text { size } \\
(\mathrm{nm})\end{array}$ \\
\cline { 2 - 4 } & Low & High & & & \\
\hline 10Pt/A & 370 & 857 & 32 & 0.67 & 1.8 \\
10Pt10Sn/A & 377 & 913 & 15 & 0.30 & 3.8 \\
5Pt15Sn/A & 378 & 850 & 7 & 0.29 & 2.9 \\
15Pt5Sn/A & 382 & 843 & 30 & 0.39 & 3.9 \\
\hline
\end{tabular}




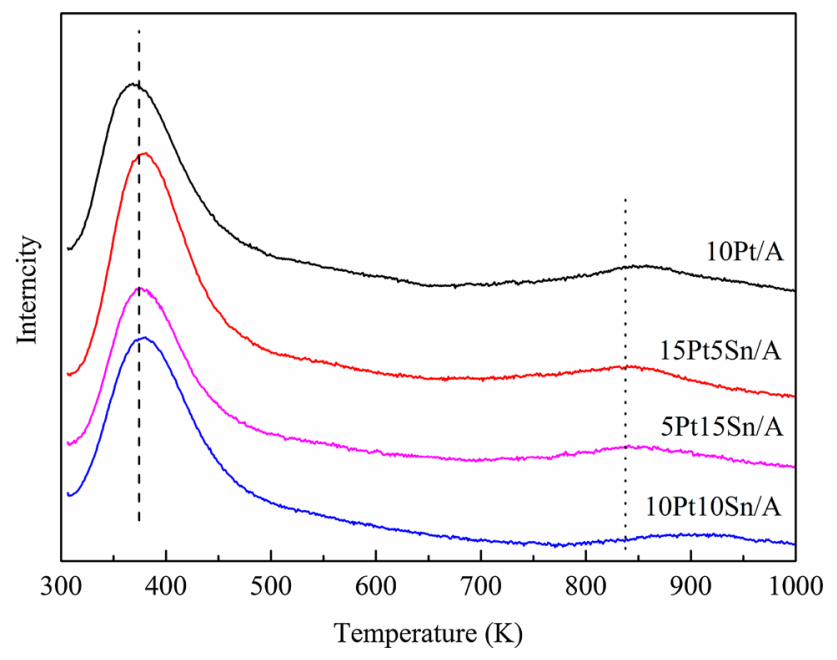

Fig. $4 \mathrm{H}_{2}$-TPD profiles of the catalysts

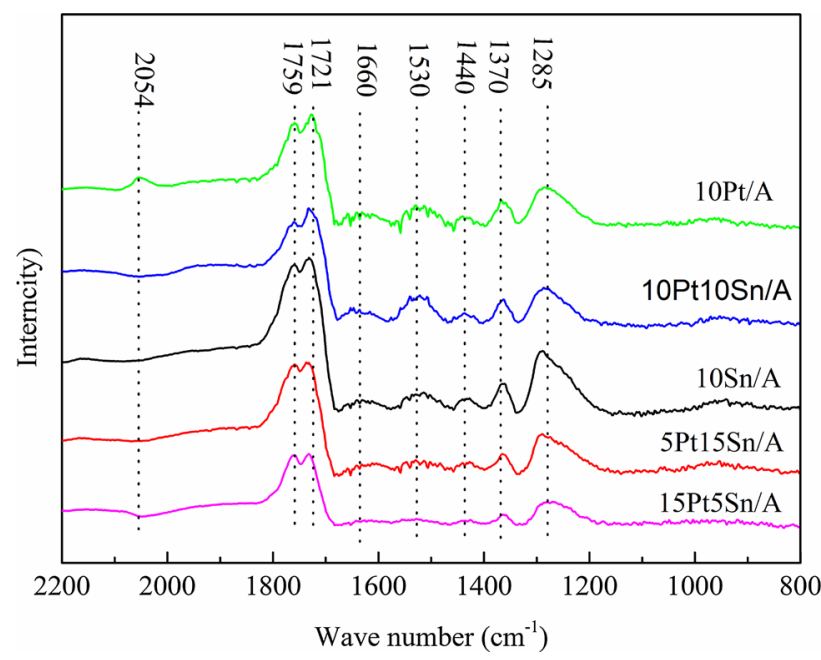

Fig. 5 DRIFTS of the catalysts after the adsorption of acetic acid

chemisorbed hydrogen and hydrogen in subsurface layers of the platinum [22].

\subsection{DRIFTS}

Infrared spectra of species resulting from acetic acid adsorption on catalysts were obtained after the introduction of acetic acid to the reduced catalysts for $0.5 \mathrm{~h}$, followed by purging the reactor cell for $1.5 \mathrm{~h}$ with high purity $\mathrm{N}_{2}$ $(99.99 \%)$ at atmospheric pressure and room temperature. Figure 5 show infrared spectra after adsorption of acetic acid on the monometallic and bimetallic catalysts. Four different surface species can be identified-acyl, acetate, adsorbed acetic acid and $\mathrm{CO}$, the detailed assignment of bands can be found in literature [9]. All catalysts show almost the same spectra except that the band at $2,054 \mathrm{~cm}^{-1}$ assigned to adsorbed $\mathrm{CO}$ on 10Pt/A disappeared after the introduction of $\mathrm{Sn}$, which indicates that the presence of $\mathrm{Sn}$ can modify the property of Pt and deter the decarbonylation of acetic acid [28]. This phenomenon can be accounted for the dramatical differences of activity and product distribution between monometallic $\mathrm{Pt}$ and bimetallic PtSn catalysts.

\subsection{XPS}

XPS experiments were performed to determinate the chemical state of $\mathrm{Pt}, \mathrm{Sn}$ in the fresh and reduced catalysts. It is hard to discriminate metal oxidation states by XPS and the data revealed by different authors contradict. Pt $4 \mathrm{~d}$ lines were analyzed instead of $\mathrm{Pt} 4 \mathrm{f}$ because the energy region of $\mathrm{Pt} 4 \mathrm{f}$ was overlapped by the intense $\mathrm{Al} 2 \mathrm{p}$ peak. From $\mathrm{Pt}$ $4 d_{5 / 2}$ spectrum of the calcined catalysts, only one peak locating at 316.1-317.2 eV was found, which can be assigned to $\mathrm{Pt}^{4+}$ or $\mathrm{Pt}^{2+}$ species [19, 29]. After reduction, the peak shifted to the region of $313.3-313.8 \mathrm{eV}$ and can be ascribed to $\mathrm{Pt}^{0}$ [19]. Figures 6 and 7 show the $\mathrm{Sn} 3 \mathrm{~d}_{5 / 2}$ spectrum of calcined and reduced catalysts. All the calcined catalysts show one sharp peak (486.6-487.1 eV) while the spectrum of the reduced catalysts can be resolved into 2 peaks (485.2-485.8 eV and $486.2-487.0 \mathrm{eV}$, respectively). The component at lower $\mathrm{BE}$ corresponds to zero-valent $\mathrm{Sn}$ or alloyed $\mathrm{Sn}$, and that located at higher region can be ascribed to oxidic Sn [29-31, 32].

The quantitative results of XPS are shown in Table 3. Compare the atom ratio of fresh and reduced $\mathrm{Pt}, \mathrm{Sn}$ monometallic catalysts, one can find out that $\mathrm{H}_{2}$ reduction can prompt the aggregation of Pt and Sn to the surface of the catalysts. As to the Pt-Sn bimetallic catalysts, $\mathrm{H}_{2}$ reduction lowered the atom ratio of $\mathrm{Pt} / \mathrm{Al}$ while increased that of $\mathrm{Sn} / \mathrm{Al}$, which means that the addition of $\mathrm{Sn}$ can restrict the reduction of $\mathrm{Pt}$ and that is in agreement with the result of $\mathrm{H}_{2}$-TPR. Similar observations were made by different authors on supported Pt-Sn catalysts [18, 33, 34]. One plausible reason is that $\mathrm{H}_{2}$ reduction can lead to the formation of PtSn alloy or that $\mathrm{Sn}$ can be transferred to $\mathrm{Pt}$ surfaces and formed $\mathrm{Pt}-\mathrm{SnO}_{\mathrm{x}}$ species.

\subsection{Electron Microscopy Techniques}

The morphology and size distribution of the active metal particles were further investigated by TEM and the typical images of $10 \mathrm{Pt} / \mathrm{A}, 10 \mathrm{Pt} 10 \mathrm{Sn} / \mathrm{A}$ and $10 \mathrm{Sn} / \mathrm{A}$ are shown in Fig. 8. At first sight, all the samples are consisted of agglomerated large particles of alumina and small round metal granules, whereas the boundary of metal particles on $10 \mathrm{Sn} / \mathrm{A}$ is less clear than that of the samples containing $\mathrm{Pt}$ and the particle size is larger. Result from statistics (calculated from the formula: average particle size $=\sum \mathrm{n}_{\mathrm{i}} \mathrm{d}_{\mathrm{i}}^{3} /$ 

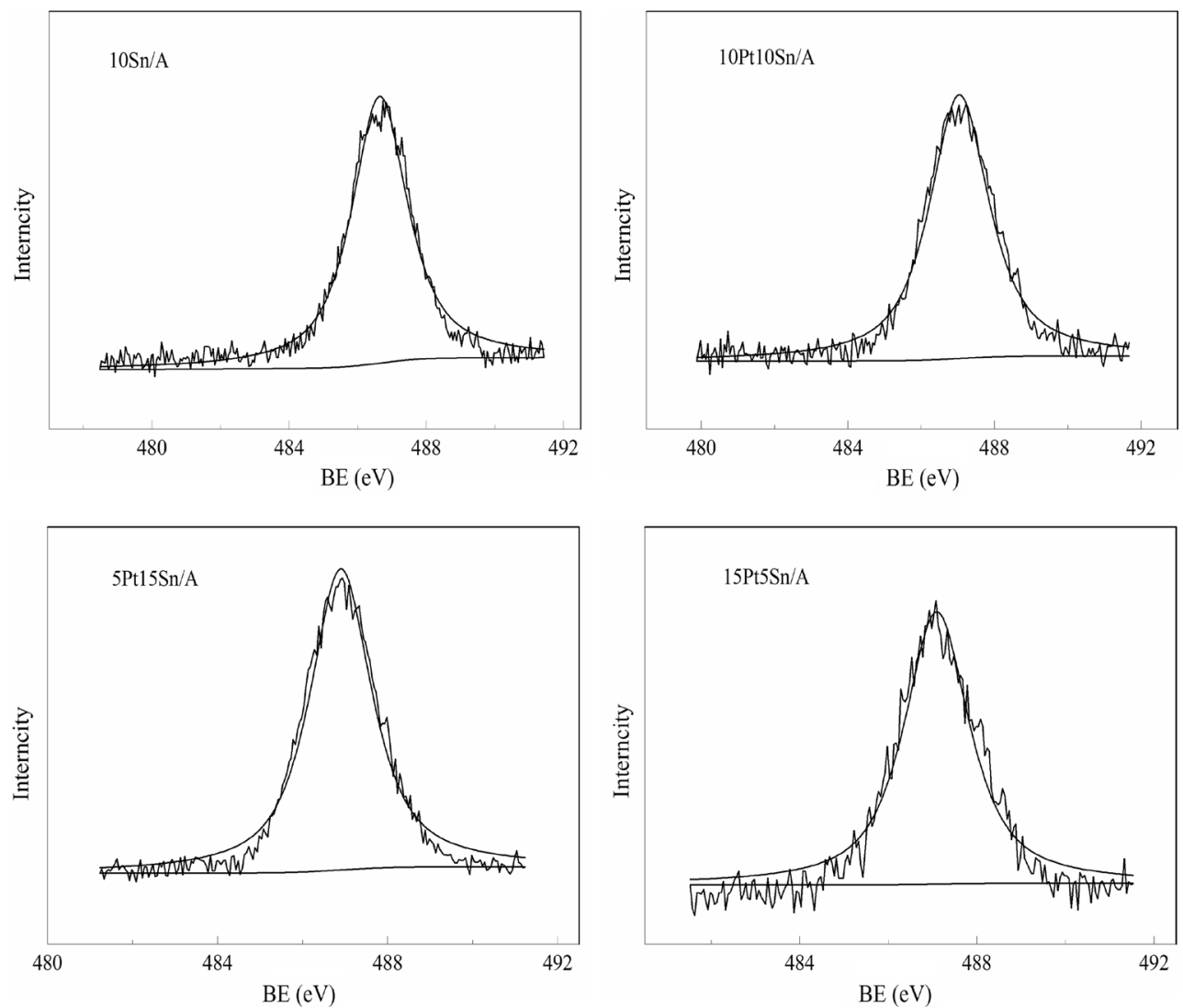

Fig. 6 The $3 d_{5 / 2}$ spectrum of the fresh catalysts

$\sum \mathrm{n}_{\mathrm{i}} \mathrm{d}_{\mathrm{i}}^{2}$ ) also demonstrated the average particle size decreased from $5 \mathrm{~nm}$ for $10 \mathrm{Sn} / \mathrm{A}$ to $3.3 \mathrm{~nm}$ for $10 \mathrm{Pt} 10 \mathrm{Sn} / \mathrm{A}$ and $1.9 \mathrm{~nm}$ for $10 \mathrm{Pt} / \mathrm{A}$. The difference between $10 \mathrm{Pt} / \mathrm{A}$ and 10Pt10Sn/A probably can be explained in terms of alloy formation or that $\mathrm{Pt}$ is covered by $\mathrm{SnO}_{\mathrm{x}}$ species in its vicinity.

To investigate the nature of metallic phases on the bimetallic catalysts, 10Pt10Sn/A was further characterized by HRTEM and EDX. Figure 9 depicts representative lattice fringe images of PtSn particles and their corresponding EDX analysis of 10Pt10Sn/A after reduction. The particles showed low contrast with respect to the alumina background and were very hard to detect. The image of one region (region I) of the catalyst shows the lattice spacings of 0.203 and $0.215 \mathrm{~nm}$ and the EDX analysis confirms the presence of both Pt and Sn. Thus, this structure can be attributed to a PtSn alloy by comparison with the lattice parameters of the (110) and (102) reflection planes of the PtSn alloy according to PDF card \#25-0614. Another region (region II) of the catalyst exhibits a lattice spacing of $0.192 \mathrm{~nm}$ and can be assigned to Pt because the lattice parameter of 220 plane of $\mathrm{Pt}$ is $0.196 \mathrm{~nm}$ (PDF card \#04-0802). However, EDX shows a bimetallic composition though the signals of Sn are very weak. Furthermore, XPS result from Table 3 demonstrates that $54 \%$ of the Sn on the reduced 10Pt10Sn/A catalyst was in the state of oxidic species. Thus, the Pt on region II is probably in the vicinity of oxidic Sn species and formed Pt$\mathrm{SnO}_{\mathrm{x}}$ species. Combining the results of TPR, XPS, HR-TEM and EDX, it can be noted that both PtSn alloy and Pt-SnO are formed on the surface of reduced PtSn catalyst.

\subsection{Acetic Acid Hydrogenation}

A number of reactions [14] related to acetic acid can occur on supported Pt catalysts as listed in Eqs. (1-6).

$$
\begin{aligned}
& \mathrm{CH}_{3} \mathrm{COOH}+2 \mathrm{H}_{2} \leftarrow \mathrm{C}_{2} \mathrm{H}_{5} \mathrm{OH}+\mathrm{H}_{2} \mathrm{O} \\
& \mathrm{CH}_{3} \mathrm{COOH}+\mathrm{H}_{2} \leftarrow \rightarrow \mathrm{CH}_{3} \mathrm{CHO}+\mathrm{H}_{2} \mathrm{O} \\
& \mathrm{CH}_{3} \mathrm{COOH}+\mathrm{C}_{2} \mathrm{H}_{5} \mathrm{OH} \leftarrow \rightarrow \mathrm{C}_{2} \mathrm{H}_{5} \mathrm{OCOCH}_{3}+\mathrm{H}_{2} \mathrm{O} \\
& \mathrm{C}_{2} \mathrm{H}_{5} \mathrm{OH}+\mathrm{H}_{2} \leftarrow \rightarrow \mathrm{C}_{2} \mathrm{H}_{6}+\mathrm{H}_{2} \mathrm{O} \\
& \mathrm{CH}_{3} \mathrm{COOH}+\mathrm{H}_{2} \leftarrow \rightarrow \mathrm{CH}_{4}+\mathrm{CO}+\mathrm{H}_{2} \mathrm{O} \\
& \mathrm{CH}_{3} \mathrm{COOH} \leftarrow \rightarrow \mathrm{CO}_{2}+\mathrm{CH}_{4}
\end{aligned}
$$

Apart from ethanol and ethyl acetate (originated from the esterification of ethanol and acetic acid), there are also 

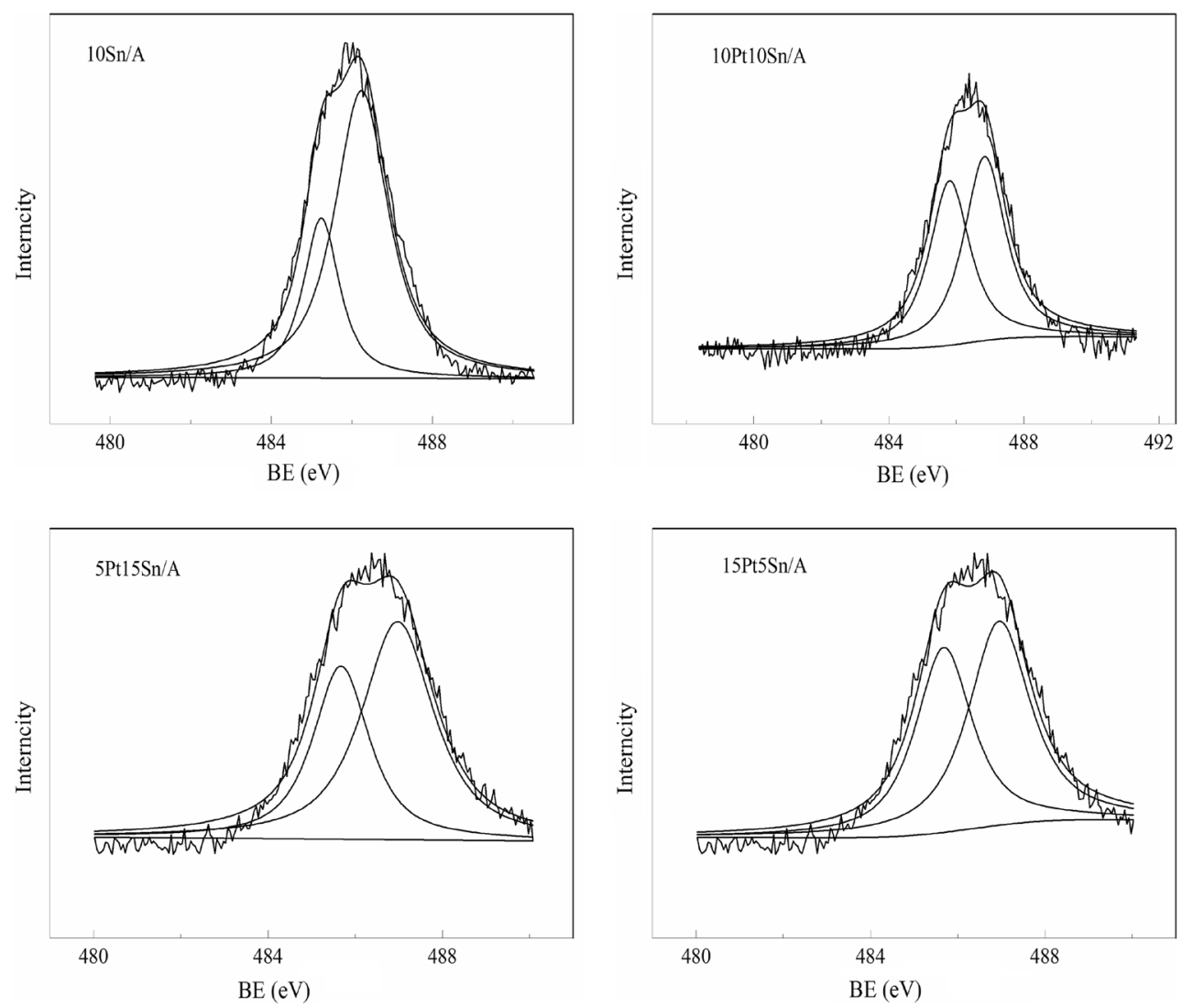

Fig. 7 The $3 d_{5 / 2}$ spectrum of the reduced catalysts

a small amount of $\mathrm{CH}_{4}, \mathrm{C}_{2} \mathrm{H}_{6}$ and acetaldehyde in the products. The conversion of acetic acid and the selectivity of products were calculated by formula (7) and (8):

$$
\begin{aligned}
& X_{\mathrm{CH}_{3} \mathrm{COOH}} \%=\frac{n\left(\mathrm{CH}_{3} \mathrm{COOH}\right)_{\text {in }}-n\left(\mathrm{CH}_{3} \mathrm{COOH}\right)_{\text {out }}}{n\left(\mathrm{CH}_{3} \mathrm{COOH}\right)_{\text {in }}} \\
& \times 100 \% \\
& S_{i} \%=\frac{n_{i} v_{i}}{n\left(\mathrm{CH}_{3} \mathrm{COOH}\right)_{\text {in }}-n\left(\mathrm{CH}_{3} \mathrm{COOH}\right)_{\text {out }}} \times 100 \%
\end{aligned}
$$

where $n\left(\mathrm{CH}_{3} \mathrm{COOH}\right)_{\text {in }}$ and $\mathrm{n}\left(\mathrm{CH}_{3} \mathrm{COOH}\right)_{\text {out }}$ are the flow rate of acetic acid at inlet and outlet, and $n_{i}$ and $v_{i}$ represent the flow rate of product $i$ and the stoichiometry of product i, respectively.

\subsection{Performance of the Catalysts}

The performances of all the catalyst, both monometallic and bimetallic, were tested at $548 \mathrm{~K}, 2 \mathrm{MPa}$, LHSV $=0.6 \mathrm{~h}^{-1}, \mathrm{H}_{2} / \mathrm{HOAC}=10$, and the results are presented in Table 4 . The activity in terms of acetic acid conversion follows the trend of 10Pt10Sn/A $>15 \mathrm{Pt} 5 \mathrm{Sn} /$ $\mathrm{A}>5 \mathrm{Pt} 15 \mathrm{Sn} / \mathrm{A}>10 \mathrm{Pt} / \mathrm{A}>10 \mathrm{Sn}$. The monometallic catalyst of $10 \mathrm{Sn} / \mathrm{A}$ and $10 \mathrm{Pt} / \mathrm{A}$ show distinct performance. The acetic acid conversion of $10 \mathrm{Sn} / \mathrm{A}$ is only $2 \%$ and the main product is acetone $(79 \%)$ while 10Pt/A can achieve $10 \%$ conversion and a large portion of $\mathrm{CH}_{4}(22 \%)$ emerged, which is originated from acetic acid decarbonylation. Selectivity of aldehyde shows little variation because it is a primary product of acetic acid reduction and it can be hydrogenated to ethanol quickly. Compare monometallic Pt catalyst with bimetallic PtSn catalysts, one can find out that the addition of Sn can exert 2 remarkable impacts. For one thing, the conversion of acetic acid increased dramatically; for the other thing, the production of $\mathrm{CH}_{4}$ was suppressed sharply. The observed promotional effect of $\mathrm{Sn}$ addition could be related to the formation of PtSn alloy and the existence of oxidized tin on platinum particles $\left(\mathrm{Pt}-\mathrm{SnO}_{\mathrm{x}}\right)$. One proposal is that the oxidized metal species act as electrophilic or Lewis acid sites for the adsorption and activation of the $\mathrm{C}=\mathrm{O}$ bond and enhance the activity of hydrogenation of $\mathrm{C}=\mathrm{O}$ [34]. Another explanation is that the formed PtSn alloy particles can change the electronic properties of $\mathrm{Pt}$ and decrease the size of the surface $\mathrm{Pt}$ ensembles, thus inhibiting the cleavage of $\mathrm{C}-\mathrm{C}$ and $\mathrm{C}-\mathrm{O}$ bond that lead to the production of $\mathrm{CH}_{4}$ and $\mathrm{C}_{2} \mathrm{H}_{6}$. Previous studies of acetic acid hydrogenation mainly focused 
Table 3 The quantitative results of XPS

\begin{tabular}{|c|c|c|c|c|c|}
\hline \multirow[t]{2}{*}{ Sample } & \multicolumn{2}{|c|}{$\begin{array}{l}\text { Atom ratio } \\
(\%)\end{array}$} & \multicolumn{3}{|l|}{$\mathrm{BE}(\mathrm{eV})$} \\
\hline & $\begin{array}{l}\mathrm{Pt} / \\
\mathrm{Al}\end{array}$ & $\begin{array}{l}\mathrm{Sn} / \\
\mathrm{Al}\end{array}$ & $\mathrm{Pt}$ & Sn & \\
\hline $10 \mathrm{Pt} / \mathrm{A}$ & 2.4 & - & $\begin{array}{l}316.2 \\
\quad(100 \%)\end{array}$ & - & - \\
\hline $10 \mathrm{Pt} / \mathrm{A}^{\mathrm{a}}$ & 2.9 & - & $\begin{array}{l}313.3 \\
\quad(100 \%)\end{array}$ & - & - \\
\hline $10 \mathrm{Sn} / \mathrm{A}$ & - & 7.5 & - & - & $\begin{array}{l}486.6 \\
\quad(100 \%)\end{array}$ \\
\hline $10 \mathrm{Sn} / \mathrm{A}^{\mathrm{a}}$ & - & 15 & - & $\begin{array}{l}485.2 \\
\quad(27 \%)\end{array}$ & $\begin{array}{l}486.2 \\
\quad(73 \%)\end{array}$ \\
\hline 5Pt15Sn/A & 1.9 & 11.5 & $\begin{array}{l}316.1 \\
\quad(100 \%)\end{array}$ & - & $\begin{array}{l}486.9 \\
\quad(100 \%)\end{array}$ \\
\hline $\begin{array}{l}5 \mathrm{Pt} 15 \mathrm{Sn} / \\
\mathrm{A}^{\mathrm{a}}\end{array}$ & 1.2 & 13 & $\begin{array}{l}313.5 \\
\quad(100 \%)\end{array}$ & $\begin{array}{l}485.6 \\
(38 \%)\end{array}$ & $\begin{array}{l}486.9 \\
\quad(62 \%)\end{array}$ \\
\hline $\begin{array}{l}\text { 10Pt10Sn/ } \\
\text { A }\end{array}$ & 3.1 & 8.1 & $\begin{array}{l}316.9 \\
\quad(100 \%)\end{array}$ & - & $\begin{array}{l}487 \\
\quad(100 \%)\end{array}$ \\
\hline $\begin{array}{l}10 \mathrm{Pt} 10 \mathrm{Sn} / \\
\mathrm{A}^{\mathrm{a}}\end{array}$ & 2.8 & 11 & $\begin{array}{l}313.6 \\
(100 \%)\end{array}$ & $\begin{array}{l}485.8 \\
\quad(46 \%)\end{array}$ & $\begin{array}{l}486.8 \\
\quad(54 \%)\end{array}$ \\
\hline 15Pt5Sn/A & 4.5 & 6.3 & $\begin{array}{l}317.2 \\
\quad(100 \%)\end{array}$ & - & $\begin{array}{l}487.1 \\
\quad(100 \%)\end{array}$ \\
\hline $\begin{array}{l}15 \mathrm{Pt} 5 \mathrm{Sn} / \\
\mathrm{A}^{\mathrm{a}}\end{array}$ & 3.5 & 9.8 & $\begin{array}{l}313.8 \\
\quad(100 \%)\end{array}$ & $\begin{array}{l}485.7 \\
\quad(46 \%)\end{array}$ & $487(54 \%)$ \\
\hline
\end{tabular}

${ }^{a}$ Reduced catalysts

on the reaction mechanism or kinetic behavior, and the data about acetic acid conversion and product selectivity are not much [5-8]. The ethane selectivity of $10 \mathrm{Pt} 10 \mathrm{Sn} / \mathrm{A}$ is much lower than that of $\mathrm{Pt} / \mathrm{TiO}_{2}$ and other oxide supported Pt catalysts [8]. In another study, $40 \%$ ethanol selectivity and about $10 \%$ acetic acid conversion was achieved on a $\mathrm{PtFe} / \mathrm{SiO}_{2}$ catalyst [35]. Thus, $10 \mathrm{Pt} 10 \mathrm{Sn} / \mathrm{A}$ is a promising catalyst for the hydrogenation of acetic acid to ethanol as revealed in Table 4 and the effect of temperature and pressure was studied to optimize the product selectivity.

\subsection{The Effect of Temperature on Acetic Acid Conversion and Product Selectivity}

The impact of reaction temperature on the activity and selectivity of 10Pt10Sn/A was studied from 468 to $548 \mathrm{~K}$ and displayed in Fig. 10. The original hydrogenation product aldehyde varies little in the selected temperature range and $\mathrm{CH}_{4}$ and $\mathrm{C}_{2} \mathrm{H}_{6}$ were only founded at $548 \mathrm{~K}$, so only the selectivity of aldehyde, ethanol and ethyl acetate were presented here.

It is shown that the conversion of acetic acid increased dramatically from 16 to $68 \%$ over the temperature range
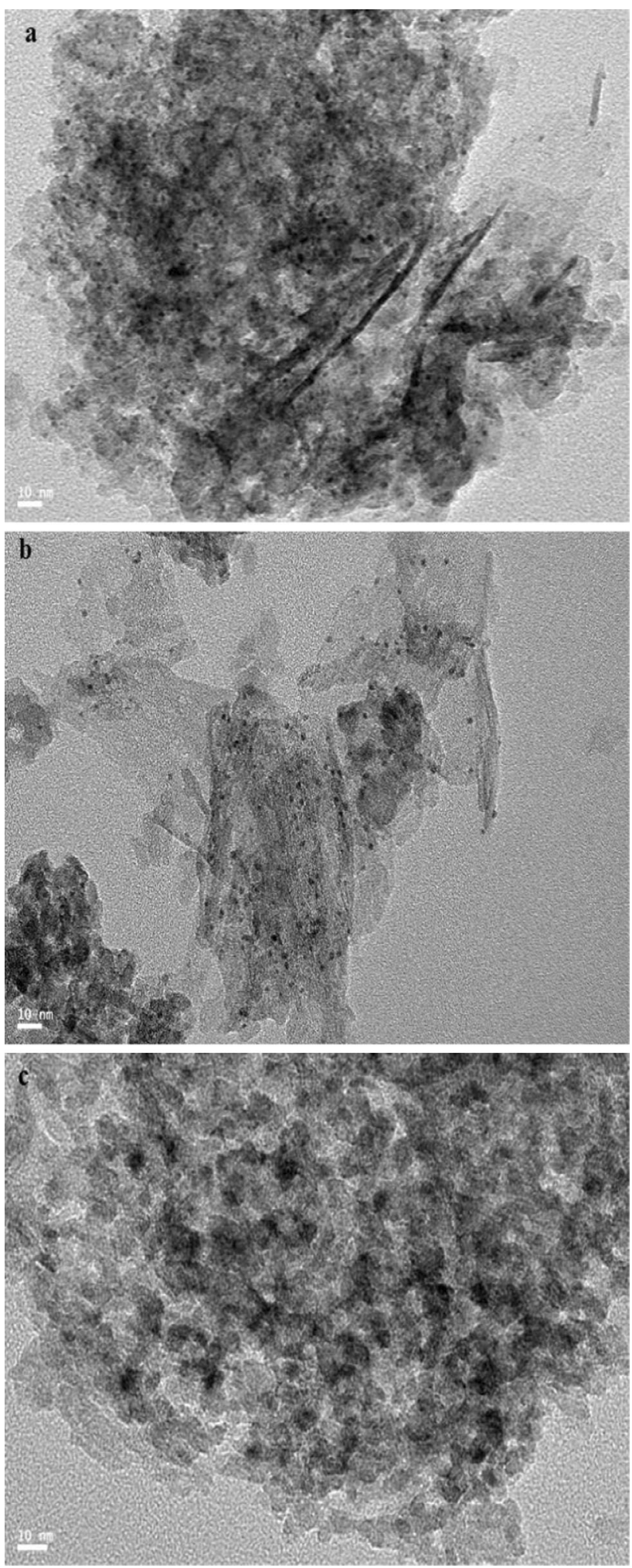

Fig. 8 TEM images of a 10Pt/A, b 10Pt10Sn/A and c 10Sn/A

studied due to the promotion of reaction rate caused by the rise of temperature. The selectivity of ethanol dropped markedly as the continued increase of temperature and the 

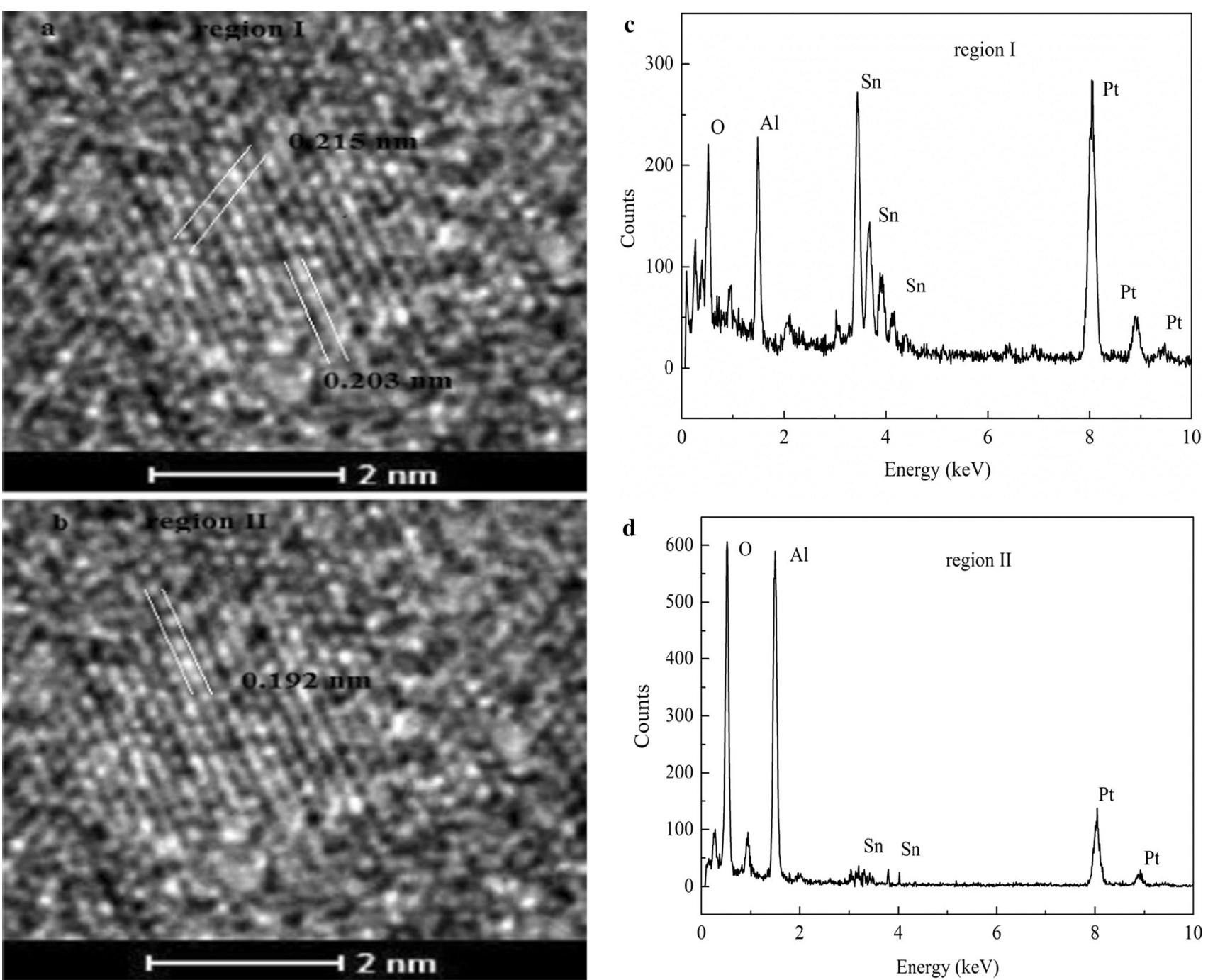

Fig. 9 Catalyst 10Pt10Sn/A: a, b Representative HRTEM micrographs and c, d corresponding EDX patterns

Table 4 The performance of the catalysts in acetic acid hydrogenation

\begin{tabular}{lllllll}
\hline Catalysts & $\mathrm{X}(\%)$ & $\mathrm{S}(\%)$ & & \\
\cline { 2 - 6 } & & $\mathrm{C}_{2} \mathrm{H}_{5} \mathrm{OH}$ & $\mathrm{C}_{2} \mathrm{H}_{5} \mathrm{OCOCH}_{3}$ & $\mathrm{CH}_{3} \mathrm{CHO}$ & $\mathrm{CH}_{4}$ & $\mathrm{C}_{2} \mathrm{H}_{6}$ \\
\hline $10 \mathrm{Pt} / \mathrm{A}$ & 10 & 36 & 36 & 2 & 22 & 6 \\
15Pt5Sn/A & 42 & 30 & 61 & 1 & 6 & 1 \\
10Pt10Sn/A & 66 & 54 & 38 & 1 & 4 & 1 \\
5Pt15Sn/A & 36 & 50 & 48 & 2 & - & - \\
10Sn/A & 2.0 & - & - & - & - & - \\
\hline
\end{tabular}

trend of selectivity of ethyl acetate is against that of ethanol, which may be caused by the difference of apparent activation energies between hydrogenation and esterification [8].

\subsection{The Effect of Pressure on Acetic Acid Conversion and Product Selectivity}

The influence of pressure has been investigated over the range of 0.1-4.0 $\mathrm{MPa}$ when other operation conditions were fixed $\left(\mathrm{T}=528 \mathrm{~K}, \mathrm{H}_{2} / \mathrm{CH}_{3} \mathrm{COOH}=10\right.$, LHSV $\left.=0.6 \mathrm{~h}^{-1}\right)$ and the results are presented in Fig. 11. The conversion of acetic acid rose with the increase of pressure, which results from the enhanced density of active acetate surface species and the improved collision probability of reactants and the active sites on catalyst surface. At the same time, the selectivity of ethanol increased while that of ethyl acetate decreased, and that can be explained from the perspective of thermodynamics. The reduction of acetic acid to ethanol and 

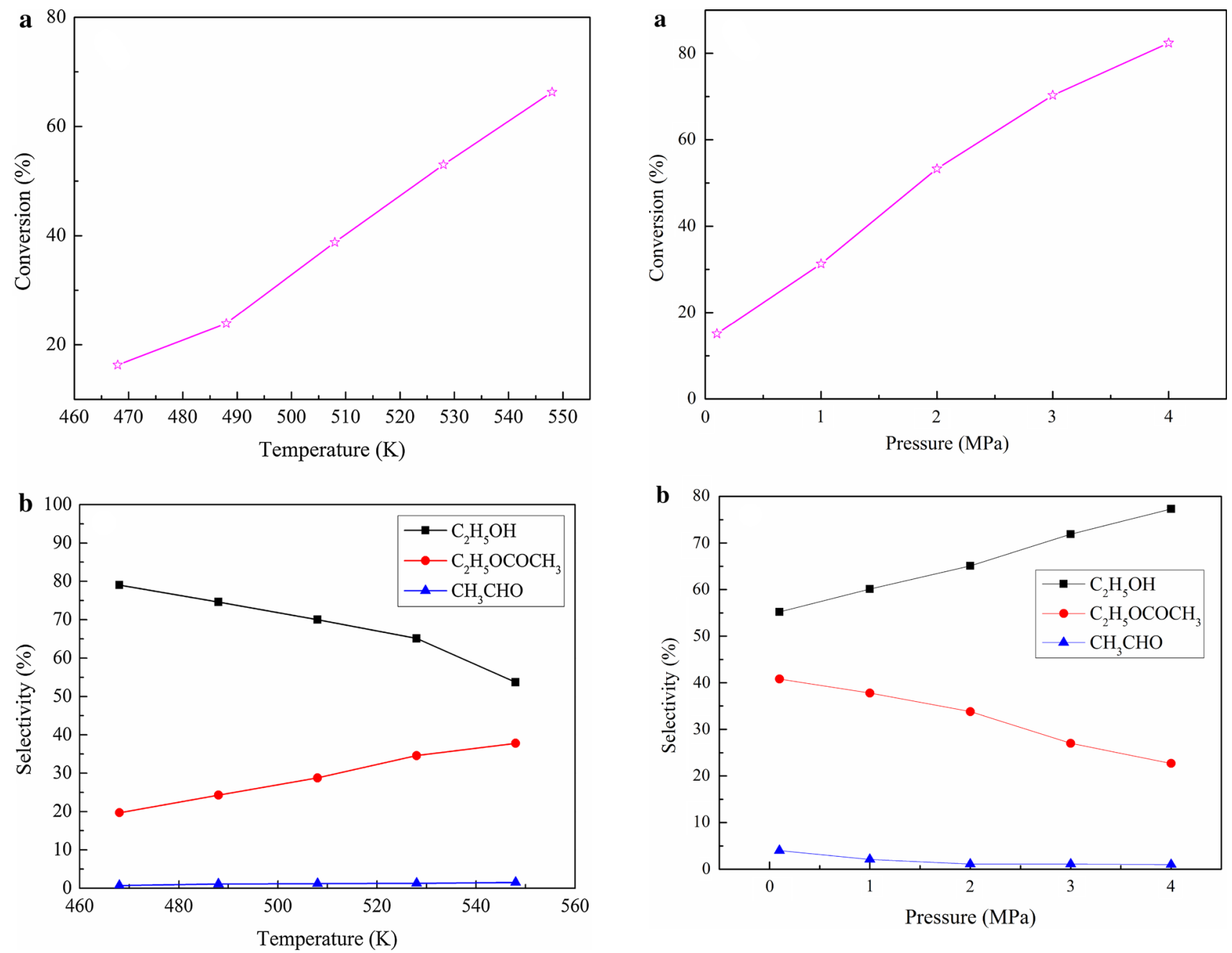

Fig. 10 The effect of temperature on a acetic acid conversion and b product selectivity over 10Pt10Sn/A

the esterification of acetic acid and ethanol to ethyl acetate are two consecutive reactions. The first one is a molecules reduced reaction while the molecule number of the second one is constant. Thus, the increase of pressure is beneficial to the production of ethanol.

\section{Conclusions}

$\mathrm{Pt} / \mathrm{Al}_{2} \mathrm{O}_{3}, \mathrm{Sn} / \mathrm{Al}_{2} \mathrm{O}_{3}$ and $\mathrm{PtSn} / \mathrm{Al}_{2} \mathrm{O}_{3}$ were prepared for the gas phase hydrogenation of acetic acid. The addition of $\mathrm{Sn}$ can enhance the catalytic activity and the selectivity towards ethanol and ethyl acetate, as well as restrain the production of $\mathrm{CH}_{4}$ and $\mathrm{C}_{2} \mathrm{H}_{6}$. Operation conditions such as

Fig. 11 The effect of pressure on a acetic acid conversion and b product selectivity over $10 \mathrm{Pt} 10 \mathrm{Sn} / \mathrm{A}$

temperature and pressure can also affect the activity and selectivity of PtSn catalyst. Results from XRD and TEM shows that metal particles are highly dispersed on alumina surface and the textural property of the support has been changed little. The shift of reduction temperature of PtSn catalyst in $\mathrm{H}_{2}$-TPR indicated that $\mathrm{Sn}$ addition may cause co-reduction of $\mathrm{Pt}$ and $\mathrm{Sn}$, thus lead to the formation of PtSn species. $\mathrm{H}_{2}$-pulse chemisorption and acetic acid DRIFTS revealed that the introduction of Sn lowered the dispersion of Pt and modify the property of Pt. At the same time, XPS demonstrated that $\mathrm{H}_{2}$ reduction is beneficial to the enrichment of $\mathrm{Pt}, \mathrm{Sn}$ on the surface of monometallic catalysts while the introduction of Sn in PtSn catalyst is detrimental to the transportation of Pt to the catalyst surface, which can be ascribed to the presence of PtSn alloy or 
Pt-SnO ${ }_{x}$ species. HRTEM and EDX revealed the presence of PtSn alloy and $\mathrm{Pt}-\mathrm{SnO}_{\mathrm{x}}$ species after the reduction of 10Pt10Sn/A. Thus, the better performance of PtSn catalysts can be attributed to the formation of PtSn alloy and Pt$\mathrm{SnO}_{\mathrm{x}}$ particles.

Acknowledgments This work is financially supported by the National Science and Technology Supporting Plan (2006BAE02B02).

Open Access This article is distributed under the terms of the Creative Commons Attribution License which permits any use, distribution, and reproduction in any medium, provided the original author(s) and the source are credited.

\section{References}

1. Maki Y, Sato K, Isobe A, Iwasa N, Fujita S, Shimokawabe M, Takezawa N (1998) Appl Catal A 170:269-275

2. Liu YY, Murata M, Inaba M, Takahara I, Okabe K (2011) Catal Today 164:308-314

3. Mei DH, Rousseau R, Kathmann SM, Glezakou VA (2010) J Catal 271:325-342

4. Yoneda N, Kusano S, Yasui M, Pujado P, Wilcher S (2001) Appl Catal A 221:253-265

5. Pestman R, Koster RM, Boellaard E, van der Kraan AM, Ponec V (1998) J Catal 174:142-152

6. Pestman R, van Duijne A, Pieterse JAZ, Ponec V (1995) J Mol Catal A Chem 103:175-180

7. Pestman R, Koster RM, Pieterse JAZ, Ponec V (1997) J Catal $168: 255-264$

8. Rachmady W, Vannice MA (2000) J Catal 192:322-334

9. Rachmady W, Vannice MA (2002) J Catal 207:317-330

10. Ayastuy JL, González-Marcos MP, Gutiérrez-Ortiz MA (2011) Catal Commun 12:895-900

11. Corro G, Fierro JLG, Romero FB (2006) Catal Commun 7:867-874

12. Corro G, Fierro JLG, Montiel R, Banuelos F (2005) J Mol Catal A 228:275-282

13. Siri GJ, Ramallo-Lópezc JM, Casella ML, Fierrod JLG, Requejo FG, Ferretti OA (2005) Appl Catal A 278:239-249

14. Bocanegra SA, de Miguel SR, Borbath I, Margitfalvi JL, Scelza OA (2009) J Mol Catal A 301:52-60
15. de Miguel SR, Bocanegra SA, Julieta Vilella IM, Guerrero-Ruiz A, Scelza OA (2007) Catal Lett 119:5-15

16. Shashikala V, Jung H, Shin CH, Koh HL, Jung KD (2013) Catal Lett 143:651-656

17. Bocanegra SA, De Miguel SR, Castro AA, Scelza OA (2004) Catal Lett 96:129-131

18. de Miguel SR, Román-Marínez MC, Jablonski EL, Fierro JLG, Cazorla-Amorós D, Scelza OA (1999) J Catal 184:514-525

19. Serrano-Ruiz JC, Huber GW, Sánchez-Castillo MA, Dumesic JA, Rodríguez-Reinoso F, Sepúlveda-Escribano A (2006) J Catal 241:378-388

20. Coloma F, Sepfilveda-Escribano A, Fierro JLG, RodriguezReinoso F (1996) Appl Catal A 136:231-248

21. Coloma F, Sepfilveda-Escribano A, Fierro JLG, RodriguezReinoso F (1996) Appl Catal A 148:63-80

22. He SB, Sun CL, Bai ZW, Dai XH, Wang B (2009) Appl Catal A 356:88-98

23. Pisduangdaw S, Panpranot J, Methastidsook C, Chaisuk C, Faungnawakij K, Praserthdam P, Mekasuwandumrong O (2009) Appl Catal A 370:1-6

24. Hoang DL, Farrage SA-F, Radnik J, Pohl M-M, Schneider M, Lieske H, Martin A (2007) Appl Catal A 333:67-77

25. Llorca J, de la Piscina PR, Fierro J-LG, Sales J, Horns N (1997) J Mol Catal A 118:101-111

26. Bariås OA, Holmen A, Blekkan EA (1996) J Catal 158:1-12

27. Yu CL, Ge QJ, Xu HY, Li WZ (2006) Appl Catal A 315:58-67

28. Margitfalvi JL, Tompos A, Kolosova I, Valyon J (1998) J Catal 174:246-249

29. Corro G, Fierro J-LG, Montiel R, Castillo S, Moran M (2003) Appl Catal B 46:307-317

30. Vu BK, Song MB, Ahn IY, Suh Y-W, Suh DJ, Kim W-I, Koh H-L, Choi YG, Shin EW (2011) Appl Catal A 400:25-33

31. Homs N, Llorca J, Riera M, Jolis J, Fierro J-LG, Sales J, de la Piscina PR (2003) J Mol Catal A 200:251-259

32. Vilella IMJ, de Miguel SR, de Lecea CS-M, Linares-Solano Á, Scelza OA (2005) Appl Catal A 281:247-258

33. Neri G, Milone C, Galvagno S, Pijpers APJ, Schwank J (2002) Appl Catal A 227:105-115

34. Homs N, Llorca J, de la Piscina PR, Rodríguez-Reinoso F, Sepúlveda-Escribano A, Silvestre-Albero J (2001) Phys Chem Chem Phys 3:1782-1788

35. Rachmady W, Vannice MA (2002) J Catal 209:87-98 